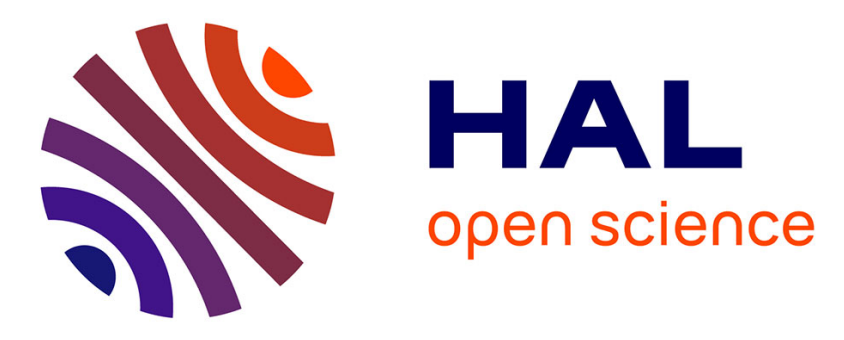

\title{
Surface water quality assessment in a semiarid Mediterranean region (Medjerda, Northern Tunisia) using partial triadic analysis
}

Noura Slimani, Juan José Jiménez, Eric Guilbert, Moncef Boumaiza, Jean Thioulouse

\section{To cite this version:}

Noura Slimani, Juan José Jiménez, Eric Guilbert, Moncef Boumaiza, Jean Thioulouse. Surface water quality assessment in a semiarid Mediterranean region (Medjerda, Northern Tunisia) using partial triadic analysis. Environmental Science and Pollution Research, 2020, 10.1007/s11356-020-09326-7 . hal-02624287

\section{HAL Id: hal-02624287 \\ https://cnrs.hal.science/hal-02624287}

Submitted on 26 May 2020

HAL is a multi-disciplinary open access archive for the deposit and dissemination of scientific research documents, whether they are published or not. The documents may come from teaching and research institutions in France or abroad, or from public or private research centers.
L'archive ouverte pluridisciplinaire HAL, est destinée au dépôt et à la diffusion de documents scientifiques de niveau recherche, publiés ou non, émanant des établissements d'enseignement et de recherche français ou étrangers, des laboratoires publics ou privés. 
Environmental Science and Pollution Research

https://doi.org/10.1007/s11356-020-09326-7

RESEARCH ARTICLE

Surface water quality assessment in a semiarid Mediterranean region (Medjerda, Northern Tunisia) using partial triadic analysis

Noura Slimani 1,2

\& Juan Još̌ Jimžnez 3

\& Eric Guilbert 1

\& Moncef Bouma・za 2

\& Jean Thioulouse 4

Received: 20 January 2020 /Accepted: 14 May 2020

Springer-Verlag GmbH Germany, part of Springer Nature 2020

\section{Abstract}

A range of methods have been developed specifically to analyze several tables of data simultaneously (variable. space. time) in the field of ecological research, although they have been less widely used to examine water quality. In this study, we assessed the spatiotemporal variability of water quality in the Medjerda River basin (Northern Tunisia). Partial triadic analysis (PTA) provides an effective framework for the assessment of spatiotemporal variability of water quality in the Medjerda River basin (Northern Tunisia). Fourteen physicochemical variables were monitored from 12 sampling sites monthly during 2013. PTA allowed correlations among different physicochemical parameters to be identified and to assess overall water quality in the Medjerda River. Salinity (S), $\mathrm{Cl} ., \mathrm{SO} 42 ., \mathrm{Ca} 2+$, and $\mathrm{Mg} 2+$ ions were associated with intensive agricultural activities (agricultural pollution sources) leading to salinization. However, $\mathrm{NH} 4+, \mathrm{PO} 43$. , chemical oxygen demand (COD), and biochemical oxygen demand (BOD5) we more strongly associated with polluted urban sites. PTA helped illustrate that strong links exist between land uses and adjacent water quality. The advantages of this multi-table method approach for water quality monitoring include as follows: (1) identifying common multivariate spatial structures and problems associated with maintaining water quality, (2) allowing iden.tification of consistent patterns in water chemistry, and (3) allowing analysis on the temporal variability of water chemistry.

Keywords

Medjerda River basin. Spatiotemporal assessment. Water quality . Multivariate statistics . Partial triadic analysis

Introduction

Freshwater ecosystems, specifically streams and rivers, are one of the most endangered ecosystems in the world due to the combined effects of natural variability (e.g., geological, hydro.logical, and climatic) and increased anthropogenic activities (e.g., rapid industrialization and agriculture resulting in the widespread use of chemical fertilizers and pesticides; Dudgeon et al. 2006; Ormerod et al. 2010; Woodward et al. 2010; Domisch et al. 2013). In many agricultural watersheds, the deg.radation of water quality is frequently caused by runoff from fields, due to the excessive application of nitrogen or phosphate fertilizers (Allan 1995; Zhang et al. 2007; Rao et al. 2009). As a result, agricultural is responsible for the runoff and leaching of excess pesticides and nutrients into surface water and ground.water across the globe (e.g., Zalidis et al. 2002). 
The study of watershed pollution and the interactions among pollutants are complex. This is why hydrologists examine spatial and temporal heterogeneity of water quality to identify pollution sources resulting from urban runoff and drainage ditches, and agricultural and mining activities (non-point and point) to address eutrophication salinization acidificationeffects(Zalidisetal. 2002). In Europe, the Water Framework Directive (WFD 2000/60/ CE) uses river basins as the fundamental management unit (Commission of the European Communities 2000; Molle 2009) to develop modeling approaches for sustain.able management of water resources at the scale of the river basin.

Multivariate statistical analysis techniques are commonly used in a twodimension manner to evaluate spatial and tem.poral variation in water quality at the watershed scale (Gourdol et al. 2013). However, when the objectives of the analyses concern both spatial and temporal variability simul.taneously, traditional multivariate methods are not always ap.propriate. Alternative multi-dimensional methods, called three-way multivariate or K-table analysis, have been specif.ically designed to analyze several datasets simultaneously (Thioulouse and Chessel 1987; Jimžnez et al. 2006; Jimžnez et al. 2015). Using this approach, data is presented as a chro.nologicalseriesofmatrices ( $n$ sites, p variables, $k$ times) with information being provided in data cube format. This ap.proach allows spatial structure common to every temporal matrix to be identified and to study its temporal stability. This approach is more commonly called partial triadic analy.sis (PTA).

A range of studies have used PTA to characterize the spa.tiotemporal variability in ecological datasets (Blanc and Beaudou 1998; Blanc et al. 1998; Gaertner 2000;Rossi 2003; Cadet et al. 2005; Ernoult et al. 2006; JimŽnez et al. 2006; Rolland et al. 2009). However, PTA has rarely been used to date to examine water quality, although two studies are relevant to the present study. The first analyzed the spatial and temporal patterns of water quality in a river basin in north.eastern spain (Darwiche-Criado et al. 2015), and the second examined pollution in agricultural landscapes of a river in northeastern spain (Jimžnez et al. 2015). However, there has been limited use of this multi-way analysis method to evaluate the aquatic ecosystems of Northern African countries, espe.cially the impacts of agricultural practices on water quality.

In this study, we used twelve temporal matrices (twelve sampling dates) based on observations (sampling points) for òqó variables (environmental variables). All temporal data matrices were analyzed by means of partial triadic analysis (PTA). Our objective was to determine the effectiveness of PTA in monitoring the spatial and temporal structures of water quality variability at the catchment scale in North Africa in order to determine the degree of water pollution in both an.thropogenic and natural settings.

Materials and methods

Study area

The research was carried out in the Medjerda watershed (Tunisia) (Fig. 1, Table 1). The Medjerda is one of the princi.pal catchments in North Africa, covering an area of $23,500 \mathrm{~km} 2$, of which 15,900 km2 (nearly 70\%) are in Tunisia and a length of around $500 \mathrm{~km}$ (Slimani et al. 2017), and plays an important role in TunisiaÕs water resource management strategy 
for drinking water and irrigation (Jaouadi et al. 2012).

The geological structure of the catchment is defined by Kabylo-Kroumir groundwater, the Medjerda pit, the Diapirs zone, and the Kalaat-landalous plain, before flowing into the Mediterranean sea (Kallel et al. 1974). The headwaters are dominated by Triassic rocks, and the downstream sections dominated by Cretaceous limestone rocks. The catchment is located in the sub-humid to semiarid climate zone, similar to the Mediterranean subtropics being characterized by a mild and wet winter and a hot and dry summer (Dungan et al. 2002).

\section{Physicochemical parameters}

Water samples for analysis of environmental parameters were collected $10 Đ 50 \mathrm{~cm}$ below the surface in $2-\mathrm{L}$ bottles from the center of each Òwadió and stored in the dark at 4 iC until they were analyzed. Water

temperature (T) was measured using a mercury glass thermometer graduated at 0.1 iC intervals. Salinity (S), dissolved oxygen (OXY), and $\mathrm{pH}$ were measured in situ using a portable multiparameter (WTW, MPP350).

Flow velocity (FS) was measured as the time a float (cork stopper) took to cover $1 \mathrm{~m}$. Turbidity (TUR) was measured in the laboratory using a turbidimeter (Hach Model 2100A). Calcium (Ca2+) and magnesium (Mg2+) concentrations were determined using inductively coupled plasma optical emission spectrometry (ICP-OES). Orthophosphate concentration (PO43.) was determined spectrometrically by colorimetry. The concentrations of ammonium (NH4+), nitrate (NO3.), chloride (Cl.), and sulfate (SO42.) were determined using liquid chromatography. Determination of chemical oxygen demand (COD) was based on measuring the amount of potas.sium dichromate (K2Cr207) consumed by the dissolved solids in suspension. Biochemical oxygen demand after 5 days (BOD5) was measured by incubation of the water sample in the presence of a phosphate and allyl thiourea solution in darkness and at 20 iC.

Multivariate statistical analysis

Partial triadic analysis

Partial triadic analysis (PTA) (Thioulouse and Chessel 1987; Kroonenberg 1989; Thioulouse et al. 2004; Rossi et al. 2014) was carried out to analyze the data matrices in a three.dimensional array (Fig. 2). In this study, we used twelve tem.poral matrices (twelve sampling dates) that described obser.vations (sampling points) for Òqó variables (the environmental variables). The aim of this method is to define a multivariate structure that is expressed over the different dates. The PTA method proceeds in three stages: (1) The inter-structure step builds an RV coefficient matrix between the tables (Escoufier

Fig. 1 Location of the sampling stations within the Medjerda basin study area

1973; Thioulouse et al. 2018). The components of the first eigenvector of this matrix are used as weighting and allow the construction a linear combination of the tables called the compromise. (2) The compromise analysis provides an indi.cation of the variables with similar patterns at different dates and a description of the sampling sites as a function of this typology of variables. (3) The intra-structure analysis (repro.ducibility of the compromise) summarizes the variability in the 
tables around the common structure defined by the com.promise. It highlights the elements that best fit (or do not fit) the structure of the compromise (for further details, see Thioulouse et al. 2004, Jimžnez et al. 2015, and Thioulouse et al. 2018). Computation and graphical presentation were undertaken and prepared using the ade4 package (Thioulouse et al. 2018) for the R software (R Core Team 2019).

Results

The mean values and SD of all variables water quality and hydrological variables from each sampling site analyzed are presented in Table 2. The Medjerda displayed salinity values that increased from upstream to downstream longitudinally within the watershed. The $\mathrm{pH}$ and temperatures values record.ed were typically above 7.4 and $14.5 \mathrm{iC}$ respectively. The

Table 1 List of sampling sites within the Medjerda basin study Code Location GPS Altitude (m)

ST1 Chardimou 36; 27. 01.87. NĐ08; 26. 01.56. E 197

ST2 Chemtou 36i 30.00.38. NĐ08i 34. 33.23. E 173

ST3 Beja 36i 44.11.04. NĐ09i 13. 25.15. E 147

ST4 Mellegue 36; 31. 42.18. NĐ08; 50. 28.93. E 136

ST5 Kasseb 36i 37. 22.90. NĐ09i 00. 17.52. E 130

ST6 Bouhertma 36 i 38. 05.44. NĐ08; 55. 53.35. E 131

ST7 Tessa 36i 34.05.91. NĐ08i 53. 51.98. E 127

ST8 Battan 36i 48. 29.99. NĐ09i 50.53.43. E 24

ST9 Jedeida 36i 50. 52.00. NĐ09i 56.05.03. E 23

ST10 Chafrou 36i 4.54.67. NĐ09i 56.54.62. E 18

ST11 Khlaidia 36; 57. 02.71. NĐ10; 05. 06.72. E 5

ST12 Klaat Andalous 37i 01. 07.45. NĐ10; 04.33.27. E 2

Fig. 2 Partial triadic analysis using the ade4 package.

The first step is to transform the set of data tables into a ktab object. This can be done with several ade4 functions, depending on the original data structure (a list of data tables, a list of duality diagrams, a within-class analysis, a set of data frames, or a couple of ktab objects). The second step consists in using the mean values of DO concentration were above $5 \mathrm{mg} \mathrm{L.1,al.though} \mathrm{ST5}$ did experience levels below $1 \mathrm{mg}$ L.1. In addition, ST5 obtained the highest values of several water quality

ade4 òptaó function that computes the partial triadic analysis and produces a pta object. The last step is to draw the graphs using the òplotó and òkplotó functions of the ade4 (or adegraphics) package. Details of this procedure are explained in Thioulouse et al. (2018)

parameters indicative of water pollution (PO43., COD, and BOD5) (Table 2). The values recorded at ST5 were markedly higher than those at the other sites for $\mathrm{Cl}$. (average $=$

Table 2 Descriptive statistics for all samples analyzed at all stations within the Medjerda basin study, Northern Tunisia

ST1 ST2 ST3 ST4 ST5 ST6 ST7 ST8 ST9 ST10 ST11 ST12

$\mathrm{pH} 7.89 \pm 0.37 .89 \pm 0.37 .84 \pm 0.357 .66 \pm 0.277 .49 \pm 0.57 .75 \pm 0.4$

$7.65 \pm 0.177 .69 \pm 0.177 .75 \pm 0.267 .62 \pm 0.237 .55 \pm 0.227 .84 \pm 0.13 \mathrm{~S}$

(PSU) $0.69 \pm 0.311 .3 \pm 0.60 .43 \pm 0.271 .22 \pm 0.730 .55 \pm 0.180 .39 \pm$ $0.21 .87 \pm 0.81 .87 \pm 0.531 .87 \pm 0.622 .83 \pm 0.733 .4 \pm 1.112 .49 \pm 0.56$ OXY (mg L.1) $6.21 \pm 1.786 .48 \pm 2.147 .21 \pm 2.576 .08 \pm 2.120 .93 \pm 0.41$ $7.04 \pm 2.016 .08 \pm 2.296 .29 \pm 1.826 .1 \pm 1.795 .18 \pm 1.965 .463 \pm 2.27$ 
$6.44 \pm 1.44 \mathrm{TUR}(\mathrm{NTU}) 5.31 \pm 5.274 .84 \pm 6.033 .26 \pm 4.1914 .65 \pm 19.32$ $10.88 \pm 12,516.93 \pm 12.926 .74 \pm 18.391 .93 \pm 1.383 .25 \pm 3.012 .21 \pm$ $2.862 \pm 1.913 \pm 6.02 \mathrm{~T}(\mathrm{i} C) 17.89 \pm 7.3516 .85 \pm 7.516 .71 \pm 7.816 .29$ $\pm 6.8215 .6 \pm 6.514 .58 \pm 7.316 .2 \pm 6.7518 .66 \pm 7.0316 \pm 6.216 .7 \pm$ $7.6115 .83 \pm 7.4118 .3 \pm 7.65 \mathrm{FS}(\mathrm{cm.1}) 81.91 \pm 3049.19 \pm 31.1138 .45 \pm$ $35.9764 .77 \pm 16.7968 .69 \pm 58,0439.08 \pm 25.5954 .81 \pm 26.8053 .51 \pm$ $20.0548 .02 \pm 21.2129 .92 \pm 18.0721 .32 \pm 12.9819 .22 \pm 12.06 \mathrm{Ca}+(\mathrm{mg}$ L.1) $141.22 \pm 16.9205 .52 \pm 106.7882 .69 \pm 32.34237 .52 \pm 28.67115 .65 \pm$ $18.2469 .33 \pm 29.26231 .3 \pm 48.89205 .67 \pm 16.35194 .3 \pm 24.36212 .55 \pm$ $57.78238 .2 \pm 76.64143 .72 \pm 34.65 \mathrm{Mg} 2+(\mathrm{mg} \mathrm{L.1}) 40.93 \pm 10.5944 .83 \pm$ $25.6816 .37 \pm 4.7766 .71 \pm 16.0121 .55 \pm 3.0824 .07 \pm 11.7286 .53 \pm 7.69$ $52.12 \pm 6.0961 .51 \pm 17.92116 .02 \pm 39.74147 .675 \pm 9.0990 .9 \pm 24.55 \mathrm{Cl}$. $(\mathrm{mg} \mathrm{L.1)} 14.48 \pm 38.0912 .6 \pm 38.5337 .67 \pm 30.056 .25 \pm 65.9983 .23 \pm$ $58.9911 .71 \pm 39.3943 .75 \pm 46.5541 \pm 59.6537 .4 \pm 62.0265 .73 \pm 102.08$ $62.37 \pm 68.9220 .02 \pm 49.77 \mathrm{so42} .(\mathrm{mg} \mathrm{L.1}) 0.22 \pm 12.10 .53 \pm 16.170 .49$ $\pm 9.060 .51 \pm 201.91 \pm 9.610 .53 \pm 43.870 .23 \pm 20.290 .65 \pm 12.050 .74$ $\pm 21.970 .8 \pm 23.090 .71 \pm 13.191 .54 \pm 6.96 \mathrm{NO} .(\mathrm{mg} \mathrm{L.1}) 314.47 \pm 1.18$ $48.05 \pm 1.3970 .53 \pm 12.51105 .67 \pm 3.4277 .5 \pm 27.3116 .37 \pm 5.35149 .95$ $\pm 18.9197 .07 \pm 14.05111 .98 \pm 12.62140 .13 \pm 29.62174 .85 \pm 4.61152 .05 \pm$ $4.41 \mathrm{NH} 4+(\mathrm{mg} \mathrm{L.1}) 139.5 \pm 0.016133 .65 \pm 0.72132 .47 \pm 0.25205 .5 \pm 0.37$ $145.97 \pm 2.68163 .9 \pm 0.49186 .45 \pm 0.14169 .75 \pm 0.48167 .75185 .42 \pm$ $0.66206 .42 \pm 0.37227 .77 \pm 2.22 \mathrm{PO} 3 .(\mathrm{mg} \mathrm{L.1}) 1.15 \pm 1.710 .15 \pm 0.01$ $0.15 \pm 0.010 .15 \pm 0.011 .57 \pm 1.050 .15 \pm 0.010 .16 \pm 0.010 .58 \pm 0.46$ $0.61 \pm 0.50 .83 \pm 0.420 .43 \pm 0.310 .15 \pm 0.01 \mathrm{COD}(\mathrm{mg} \mathrm{L} .1) 30305530$ $199.75 \pm 80.68 \quad 30 \quad 30 \quad 30 \quad 30 \quad 30 \quad 30 \quad 30$ BOD5 (mg L.1) $0.89 \pm 0.44 \quad 1.77 \pm 1.38$ $8.12 \pm 13.791 .07 \pm 1.0448 \pm 37.991 .3 \pm 0.841 .15 \pm 0.360 .94 \pm 0.29$ $1.5 \pm 0.730 .87 \pm 0.671 .1 \pm 0.620 .72 \pm 0.18$

83.23 mg L.1). According to the Nisbet and Verneaux (1970) conditions for establishing water quality categories in aquatic systems, ST5 was the only site in Rivers Class 6: particular streamĐlocal content and more or less polluted waters. ST1 experienced the highest nutrient values (NO3. and $\mathrm{NH} 4+$ ) and $\mathrm{ST} 4$ recorded the highest turbidity values.

Spatiotemporal pattern at the Medjerda watershed scale

The partial triadic analysis of the 4 crossed tables begins with a vector covariance matrixõs diagonalization between tables. As a result of this, we retained the first two axes which accounted for 75.34 and $12.36 \%$ of the total variance in the data respectively of the inter-structure analysis. The representation of the eigenvec.tors in Euclidean space indicated that all sampling dates displayed positive scores on axis 1 , indicating a structure com.mon to all dates (Fig. 3a). The inter-table size effects indicated that no inversion of the temporal structure of variables occurred. This distribution was consistent with the RV coefficient matrix (Table 3 and Fig. 3b). The matrices for January to September and July to August contributed the most to the common temporal dynamics of the variables (compromise structure), as indicated by their high representation quality (squared cosines) and their high weights. Conversely, matrices for April to June contributed less to the compromise structure.

In the compromise analysis (Fig. 3c), the main spatiotemporal patterns of the variables were highlighted by extracting only the first two axes, which explained $89.01 \%$ of the total inertia of the PCA for the compromise matrix. The first axis (61.44\% of the total variance) separated pollution variables (that is $\mathrm{PO}, \mathrm{NO}, \mathrm{BOD} 5, \mathrm{COD}$, and $\mathrm{NH}$ ) on the positive side of axis 1 from the remainder of the variables on the negative end. The 
second axis (27.57\% of the total variance) was characterized primarily by FS and T. Two main groups were distinguished with respect to the two axes, with nutrient variables (PO, NO, NH, DOC, and BOD5) grouped on the positive side of axis 1 (Fig. 3c), indicating that axis 1 reflected a pollution gradient. Axis 2 reflected salt and ion concentrations (S, Ca, $\mathrm{Mg}$, SO, and Cl) which clustered on the negative side of axis 2, indicating a mineralization/ salinization gradient. The distribution of the 12 sampling sites on the factorial plane formed by the first two axes indicated a clear separation between the site located in the urban area (ST5) from the other sites characterized by intensive agricultural on an upstream to downstream gradient on axis 2 (Fig. 3d). The urban sampling site (site 5ÑKasseb wadi) strongly influenced the data structure due to high pollution at the site. Along the second axis, sites $1,2,3$, and 6 were at opposite ends of the axis to sites 7, 10, 11, and 12, with the latter sites indicating strong mineralization in response to water drainage systems in the area downstream of Medjerda. These sites were clustered based on their relative sa.linitỹ̃Ca, Mg, and Cl (Fig. 3c). Sampling sites 4, 8, and 9 were located in areas of intensive agriculture and reflected elevated levels of sulfate, $\mathrm{pH}$, and temperature.

Fig. 3 Partial triadic analysis (PTA) on 12 sites data in the Medjerda basin from January to December 2013. a Inter-structure factor map and eigenvalues associated with each axis in partial triadic analysis. b Weight of each table (ak) in the construction of the compromise and the quality index of the compromise structure (cos2) for each original sampling date

The last step of the analysis, the intra-structure step, revealed which initial table best fitted the model expressed in the previous step. The original tables were projected as complementary tables onto axis 1 of the PCA based on the compromise table.

\section{Discussion}

The explicit aim of this study was to assess the usefulness of PTA in a Mediterranean region, to examine underlying pat.terns and relationships between the water quality variables in Medjerda watershed catchment over a 1-year period. This analysis was required as a response to the growing demand for water resources, especially for agricultural irrigation. Based on the results presented in the study, salinization was the dominant water quality issues identified across the sites examine. Partial triadic analysis allowed the identification of the intensification of soil leaching from agricultural land as the most important factor responsible for the direct impacts on aquatic ecosystem identified, and clearly illustrates the hydro.logical stress (pressure on water resources) in Tunisia (Bouraoui et al. 2005).

At the scale considered in this study, PTA indicated that land use is a critical component to consider when examining the spatiotemporal variability of water quality. This resulted in

Table 3 Matrix of the vector correlation coefficients (RV) between the tables for the 12 months of 2013. It is the components of the first eigenvector of this matrix that are used as weights of the tables to build the compromise

Jan Feb Mar Apr May Jun Jul Aug sep Oct Nov Dec

Jan 1

Feb $0.769 \quad 1$

$\begin{array}{llll}\text { Mar } & 0.874 & 0.833 & 1\end{array}$ 


$\begin{array}{llllllllllll}\text { Apr } & 0.524 & 0.489 & 0.504 & 1 & & & & & & \\ \text { May } & 0.462 & 0.459 & 0.435 & 0.758 & 1 & & & & & \\ \text { Jun } & 0.511 & 0.449 & 0.501 & 0.781 & 0.686 & 1 & & & & \\ \text { Jul } & 0.684 & 0.635 & 0.626 & 0.628 & 0.590 & 0.568 & 1 & & & \\ \text { Aug } & 0.683 & 0.647 & 0.648 & 0.639 & 0.582 & 0.607 & 0.895 & 1 & & \\ \text { Sep } & 0.665 & 0.592 & 0.651 & 0.564 & 0.612 & 0.583 & 0.783 & 0.843 & 1 & \\ \text { Oct } & 0.723 & 0.686 & 0.667 & 0.537 & 0.547 & 0.554 & 0.635 & 0.695 & 0.780 & 1 \\ \text { Nov } & 0.752 & 0.714 & 0.677 & 0.510 & 0.546 & 0.489 & 0.691 & 0.699 & 0.704 & 0.892 \\ \text { I } & & & & & & & & & & \\ \text { Dec } & 0.700 & 0.716 & 0.721 & 0.583 & 0.523 & 0.609 & 0.613 & 0.724 & 0.723 & 0.879 \\ 0.826 & 1 & & & & & & & & & \end{array}$

a clear separation of sampling sites on the first and second axis. Based on the distribution of the variables among the twelve sampling dates, Fig. 3 indicated a pollution gradient on axis 1 characterized by nutrients (NO3.,NH4+, and PO43.), COD, and BOD5. Elevated values of these variables can be attributed to industrial, biogenic, and anthropogenic (urban wastewater) pollution sources and sampling site ST5 (Kasseb wadi) (Abidi et al. 2011; Slimani et al. 2017).

However, the second axis of the compromise analysis in.dicated a gradient of increasing salinization associated with increasing concentrations in SO42.,Mg2+, and Ca2+ from up.stream (sites 1, 2, and 3) to downstream (sites 10, 11, and 12) of the Medjerda basin. This salinization gradient can be ex.plained by natural factors such as climate, geomorphology, and the hydrogeology of the region (Hamzaoui-Azaza et al. 2011; Etteieb et al. 2017; Slimani et al. 2017). Thus, the rel.atively high SO42. and Cl. concentrations (Table 2 and Fig. 3) can be explained by the effects of high evaporation and rela.tively low precipitation, on dissolved salt concentrations and dissolved oxygen (Bouma・za 1994). SO42. may also be de.rived from surface waterĐgroundwater interactions associated with the oxidation of pyrite derived from the Medjerda sand.stone (Amiri et al. 2011). Ca2+ and Mg2+ concentrations were also generally high (Table 3) and reflect the major contribu.tion of calcite dissolution in the groundwater mineralization processes of the Medjerda Sandstone, and indicate a strong association with the lithology of the dolomines and dolomite limestones from the Jurassic and Middle Triassic periods. Other studies in the region have also demonstrated statistically significant links between climatic conditions (temperature and/or precipitation) and salinization (Bouraoui et al. 2005).

Finally, given the adjacent land use of the sampling sites and the Medjerda catchment agriculture peculiarities, the in.creasing salinization can be associated with the effects of agricultural activities. The salinization of water may represent a point sources disturbance leading to pollution (Bouraoui et al. 2005; Etteieb et al. 2017). The agronomic effects of excessive fertilizer use and the potential effect of using saline water to irrigate crop, and associated land drainage, present major problems for the long-term sustainability of agricultural in the area (Katerji et al. 2005, 2009). In addition, agricultural land use is positively associated with increased stream flow velocities which suggest a substantial reduction of salinization from agricultural land surfaces where flowing water can be utilized. Agriculture has a relatively limited effect on the total phosphorus and ammonium load as reflected in the low con.centrations of PO43. $10.5 \mathrm{mg}$ L.1) recorded in the Medjerda River basin here and in previous research (Bouraoui et al. 2005). However, leaching of nitrate may be very high in some areas, resulting in contamination of the shallow aquifer. 
The use of the partial triadic analysis method provided promising results and its use in Mediterranean basins will improve data analysis of water quality monitoring data. In particular, partial triadic analysis allows natural and anthropo.genic influences (spatial and temporal) to be considered and as a result the identification of pollutant sources. It is also impor.tant for water quality monitoring programs to consider different hydrochemical parameters, at different places and at dif.ferent times to help improve modeling results.

\section{Conclusions}

The multivariate statistical analysis method of PTA was ap.plied to 12 sites of the Medjerda River basin, the largest sur.face water resource in Tunisia. This methodology provided a valuable technique to evaluate spatiotemporal variations in the environmental status of the watershed. The results indicated that the nutrient concentrations for most sampling points were relatively low and not very variable, thus indicating good wa.ter quality conditions. In addition, the concentrations of COD and BOD5 recorded indicated very low values for the majority of the sites studied with the exception of an anthropogenically influenced site (Kasseb wadiÑST5). PTA enables the identi.fication of the factors leading the degradation of water quality. The results obtained in this study revealed the very poor water quality of Kasseb wadi (high COD and BOD5). This could have adverse effects on the wider ecosystem, particularly the area subject to industrial discharges, and on the wider health of the surrounding human population.

\section{Acknowledgments}

We are grateful to Paul J. Wood for proof-reading the English version of the manuscript.

Funding information This study was financed by the cooperation pro-gram CNRS/DGRST no. 15/R0902 between France and Tunisia. N. Slimani was supported by a grant funded by ÒMinistry of High Education and Scientific Research of Tunisia.ó The sampling survey of 2013 was supported by Sciences Facultyõ Hydrobiology Laboratory in Bizerta.

References

Abidi S, Bejaoui M, Boumaiza M (2011) Influence de la pollution sur la qualitž des eaux et la mžiofaune de lõoued Kasseb (Tunisie septentrionale). Bull Soc Zool Fr 136:145Đ157

Allan JD (1995) Stream ecology: structure and function of running wa.ters. Kluwer, Dordrecht, p 388

Amiri A, Chaqui A, Hamdi Nasr I, Inoubli MH, Ben Ayed N, Tlig S (2011)

Role of preexisting faults in the geodynamic evolution of Northern

Tunisia, insights from gravity data from the Medjerda valley.

Tectonophysics 506:1Đ10

Blanc L, Beaudou D (1998) Stabilitž temporelle des structures spatiales des peuplements piscicoles des ržgions Languedoc-Roussillon et ProvenceAlpes-Ce dÕAzur. BFPP 348:23Đ45

Blanc L, Chessel D, DolŽdec S (1998) Etude de la stabilitž temporelle des structures spatiales par analyses dõune š̌rie de tableaux de relevžs faunistiques totalement apparižs. BFPP 348:1Đ21

Bouma•za M (1994) Recherches sur les eaux courantes de Tunisie. 
Faunistique, Ecologie et Biogžographie. Th $\square$ se De Doctorat Dõžtat EsSciences Biologiques. Fac. Sc. Tunis. pp 427

Bouraoui F, Benabdallah S, Jrad A, Bidoglio G (2005) Application of the SWAT model on the Medjerda river basin (Tunisia). Phys Chem Earth $30: 497 \boxplus 507$

Cadet P, Masse D, Thioulouse J (2005) Relationships between

plant.parasitic nematode community, fallow duration and soil factors in the Sudano-Sahelian area of Senegal. Agric Ecosyst Environ 108: $302 \boxminus 317$ Commission of the European Communities (2000) Directive 2000/60/EC of the European Parliament and the Council establishing a frame.work for Community action in the field of water policy. Official Journal of the European Communities, 22-12-2000: pp 72

R Core Team (2019). R: a language and environment for statistical com.puting. R Foundation for Statistical Computing, Vienna, Austria. URL https://www.R-project.org/

Darwiche-Criado N, Jimžnez JJ, Com'n FA, Sorando R, Słnchez-PŽrez JM (2015) Identifying spatial and seasonal patterns of river water quality in a semiarid irrigated agricultural Mediterranean basin. Environ Sci Pollut Res 22:18626Đ18636

Domisch S, Arao MB, Bonada N, Pauls SU, JŠhnig SC, Haase P (2013) Modelling distribution in European stream macroinvertebrates un-der future climates. Glob Chang Biol 19:752Đ762

Dudgeon D, Arthington AH, Gessner MO, Kawabata ZI, Knowler DJ, LŽv $\square$ que C, Naiman RJ, Prieur-Richard AH, Soto D, Stiassny MLJ, Sullivan CA (2006) Freshwater biodiversity: importance, threats, status and conservation challenges. Biol Rev 81:163Đ182

Dungan JL, Perry JN, Dale MRT, Legendre P, Citron-Pousty S, Fortin MJ, Jakomulska A, Miriti M, Rosenberg MS (2002) A balanced view of scale in spatial statistical analysis. Ecography 25:626Đ640

Ernoult A, Freire-Diaz S, Langlois E, Alard D (2006) Are similar land.scapes the result of similar histories? Landsc Ecol 21:631Đ639 Escoufier Y (1973) Le traitement des variables vectorielles. Biometrics 29:750Đ760

Etteieb S, Cherif S, Tarhouni J (2017) Hydrochemical assessment of water quality for irrigation: a case study of the Medjerda River in Tunisia. Appl Water Sci 7:469Đ480

Gaertner JC (2000) Seasonal organization patterns of demersal assem.blages in the Gulf of Lions (north-western Mediterranean Sea). J Mar Biol Assoc UK80:777Đ783

Gourdol L, Hissler C, Hoffmann L, Pfister L (2013) On the potential for the partial triadic analysis to grasp the spatio-temporal variability of groundwater hydrochemistry. Appl Geochem 39:93Đ107

Hamzaoui-Azaza F, Ketata M, Bouhlila R, Gueddari M, Riberio L (2011) Hydrogeochemical characteristics and assessment of drinking water quality in ZeussĐKoutine aquifer, southeastern Tunisia. Environ Monit Assess $174: 283 \oplus 298$

Jaouadi M, Amdouni N, Duclaux L (2012) Characteristics of natural organic matter extracted from the waters of Medjerda dam (Tunisia). Desalination $305: 64 \boxminus 71$

Jimžnez JJ, Decaens T, Rossi JP (2006) Stability of the spatio-temporal distribution and niche overlap in neotropical earthworm assem.blages. Acta Oecol 30:299Đ311

Jimžnez JJ, Darwiche-Criado N, Sorando R, Com’n FA, Słnchez-PŽrez JM (2015) A methodological approach for spatiotemporally analyz.ing waterpolluting effluents in agricultural landscapes using partial triadic analysis. J Environ Qual 44:1617Đ1630

Kallel R, Bouzaieane S, Eoche Duval JM, Colombani J, Claude J, Lamachere JM (1974) Monographie de la Medjerda. Tome1, D.R.E. ORSTOM: $1 \nsupseteq 266$ 
Katerji N, Van Hoorn JW, Fares C, Hamdy A, Mastrorilli M, Oweis T (2005) Salinity effect on grain quality of two durum wheat varieties differing in salt tolerance. Agric Water Manag 75:85Đ91

Katerji N, Mastrorilli M, Van Hoorn JW, Lahmer FZ, Hamdy A, Oweis T (2009) Durum wheat and barley productivity in salineĐdrought en.vironments. Eur J Agron 31:1Đ9

Kroonenberg PM (1989) The analysis of multiple tables in factorial ecol.ogy. III: three-mode principle component analyse: ÒAnalyse triadique compl $\square$ teó. Acta Oecol Oec Gen 10:245Đ256

Molle F (2009) River-basin planning and management: the social life of a concept. Geoforum 40:484Đ494

Nisbet M, Verneaux J (1970) Composantes chimiques des eaux cou.rantes. Discussion et proposition de classes en tant que base dõinterpržtation des analyses chimiques. Ann Limnol 6:161Đ190

Ormerod SJ, Dobson M, Hildrew AG, Townsend CR (2010) Multiple stressors in freshwater ecosystems. Freshw Biol 55:1Đ4

Rao NS, Easton ZM, Schneiderman EM, Zion MS, Lee DR, Steenhuis TS (2009) Modeling watershed-scale effectiveness of agricultural best management practices to reduce phosphorus loading. J Environ Manag 90:1385Đ1395 Rolland A, Bertrand F, Maumy M, Jacquet S (2009) Assessing phyto.plankton structure and spatio-temporal dynamics in a freshwater ecosystem using a powerful multiway statistical analysis. Water Res 43:3155Đ3168 Rossi JP (2003) The spatiotemporal pattern of a tropical earthworm spe.cies assemblage and its relationship with soil structure. Pedobiologia 47:497Đ503

Rossi JP, Nardin M, Godefroid M, Ruiz-Diaz M, Sergent AS, Martinez-Meier A, Poques L, Rozenberg P (2014) Dissecting the space-time structure of tree-ring datasets using the partial triadic analysis. PLos One 9:1Đ13 Slimani N, Guilbert E, El Ayni F, Jrad A, Boumaiza M, Thioulouse J (2017) The use of STATICO and COSTATIS, two exploratory three-ways analysis methods: an application to the ecology of aquat.ic heteroptera in the Medjerda watershed (Tunisia). Environ Ecol Stat 24:269Đ295

Thioulouse J, Chessel D (1987) Les analyses multitableaux en žcologie factorielle. I: De la typologie dõžtat ^ la typologie de fonctionnement par lÕanalyse triadique. Acta Oecol 8:463Đ480

Thioulouse J, Simier M, Chessel D (2004) Simultaneous analysis of a sequence of paired ecological tables. Ecology 85:272Đ283

Thioulouse J, Dray S, Dufour AB, Siberchicot A, Jombart T, Pavoine S (2018) Multivariate analysis of ecological data with ade4. 330p. Springer, New York

Woodward G, Perkins DM, Brown LE (2010) Climate change and fresh.water ecosystems: im-pacts across multiple levels of organization. Philos T R Soc B: Biol Sci 365:2093Đ2106

Zalidis G, Stamatiadis S, Takavakoglou V, Eskridge K, Misopolinos N (2002) Impacts of agricultural practices on soil and water quality in the Mediterranean region and proposed assessment methodology. Agricult Ecosys Environ 88:137Đ146

Zhang MK, Wang LP, He ZL (2007) Spatial and temporal variation of nitrogen exported by runoff from sandy agricultural soils. J Environ Sci $19: 1086 \oplus 1092$

Publisherõsnote Springer Nature remains neutral with regard to jurisdic.tional claims in published maps and institutional affiliations. 